\title{
MECHANISMS OF ANALEPTIC AND ANTIGIPOXIC EFFECTS OF HETEROSIDES - (DERIVATIVES FOR SULFUR AND NITROGEN CONTAINING HETEROCYCLES)
}

\author{
Kabachna I., Ph.D. student \\ Suprun E., professor \\ Kabachnyy V., professor \\ Serdiukova $\mathrm{Yu}$.
}

Ukraine, Kharkiv, National University of Pharmacy

DOI: https://doi.org/ 10.31435/rsglobal_ws/30122018/6265

\author{
ARTICLE INFO

\section{KEYWORDS} \\ Thiopental anesthesia, \\ hypoxia, \\ analeptics, \\ antihypoxants, \\ heteroside, \\ resuscitation, \\ detoxification, \\ awakening effect, \\ respiratory center.
}

Received: 29 October 2018

Accepted: 13 December 2018

Published: 30 December 2018

\begin{abstract}
In order to expand the theoretical base of targeted search for analeptics, the awakening and antihypoxic properties of Heterosides-21, Heterosides-31 (derivatives of sulfur and nitrogen containing heterocycles) were studied and their mechanisms of action were established. Sodium thiopental $(42 \mathrm{mg} / \mathrm{kg})$ was used to simulate suppression of the respiratory and vasomotor centers of the brain. Comparative drugs were the combined analeptic sulfocamphocaine (SCC) $(20 \mathrm{mg} / \mathrm{kg})$ and antihypoxant Piracetam $(300 \mathrm{mg} / \mathrm{kg})$.

The results were obtained on the models of thiopental anesthesia and normobaric hypoxia with hypercapnia, the analysis of which allowed: to qualitatively and quantitatively assess the awakening, antihypoxic activity of the studied substances and classical preparations; their effect on the respiratory center of the brain and the behavioral responses of animals; theoretically substantiate, experimentally confirm and establish aerobic, anaerobic and detoxification mechanisms for the realization of effects in various conditions; to formulate the theoretical foundations of a targeted search for universal analeptics and antihypoxic drugs, to offer an instrumental and methodological complex for their experimental reproduction.
\end{abstract}

Citation: Kabachna I., Suprun E., Kabachnyy V., Serdiukova Yu. (2018) Mechanisms of Analeptic and Antigipoxic Effects of Heterosides - (Derivatives for Sulfur and Nitrogen Containing Heterocycles). World Science. 12(40), Vol.1. doi: 10.31435/rsglobal_ws/30122018/6265

Copyright: (C) 2018 Kabachna I., Suprun E., Kabachnyy V., Serdiukova Yu. This is an open-access article distributed under the terms of the Creative Commons Attribution License (CC BY). The use, distribution or reproduction in other forums is permitted, provided the original author(s) or licensor are credited and that the original publication in this journal is cited, in accordance with accepted academic practice. No use, distribution or reproduction is permitted which does not comply with these terms.

Introduction. The range of use of analeptic covers almost all spheres of urgent therapy for peace and wartime, as well as disaster medicine. The paradox of this group of drugs is that with such a high demand, over the past 50 years, their arsenal in the global pharmaceutical market has not only not been replenished, but even reduced to 6 drugs (in Ukraine 3), which, due to their peculiarities and shortcomings, cannot meet the needs of resuscitation [1]. This is largely due to the lack of standardized methods for assessing their effectiveness, understanding of the mechanisms of action, as well as the theoretical foundations of targeted search. Therefore, the creation of original broadspectrum analeptic agents, the development of standardized models of their pharmacological screening, the study of the mechanisms of action is a viable, promising and highly relevant problem.

Aim of the research is the selection of promising substances with an awakening effect in a series of derivatives of sulfur and nitrogen containing heterocycles (heterosides) on the proposed 
model of thiopental anesthesia (TPA), the study of their antihypoxic properties and mechanisms of action to create the theoretical foundations of a targeted search for analeptics.

Materials and methods. Analeptic (AL) (awakening) and antihypoxic (AH) properties of substances were evaluated on male non-linear white mice weighing $25-29$ g. Sodium thiopental (PJSC Kievmedpreparat, Ukraine) was used as an inhibitor of the respiratory and vasomotor centers of the brain. This medical preparation is used in medicine and veterinary medicine as an anesthetic drug $[1,13]$. For comparison, classic drugs were chosen - combined analeptic Sulfocamphocaine (SCC) (Darnitsa), stimulating the respiratory (RC) and vasomotor (VMC) brain centers [1], as well as antihypoxant Piracetam (Halychpharm), prescribed during hypoxia of the central nervous system (CNS) [12]. Optimal doses of TPA (42 mg/kg), SCC (20 mg/kg), Heterosides-21 and Heterosides-31 $(2 \mathrm{mg} / \mathrm{kg})$, Piracetam $(300 \mathrm{mg} / \mathrm{kg})$ were established experimentally [2-6,9-11, 12].

All mice were kept in plastic cages on a standard diet with free access to water in the conditions of the Central Research Laboratory of NUPh in accordance with sanitary and hygienic norms $\left(\mathrm{t}=18-23^{\circ} \mathrm{C}\right.$, humidity not more than $50 \%$, natural light mode "day -night") [7,8]. All studies were performed in accordance with the requirements of the General Ethical Principles of Experiments on Animals, methodical recommendations of the State Pharmacological Center of the Ministry of Health of Ukraine "Preclinical studies of medicines", "European Convention on the Protection of Vertebrate Animals used for experimental and other scientific purposes" (Strasbourg, 1985) and in accordance with EU Directive 2010/10/63 EU on animal experiments [8].

When studying the awakening effect of the test substances, animals were divided into 5 groups $(n=6)$. First, all the intraperitoneal injections were made with TPA $[1,6,10]$. The first group was the control group and received only TPA. The test substances and comparison preparations were also administered intraperitoneally after the animals entered the third phase of anesthesia (immobilized lateral position with uniform slow breathing), i.e. at the peak of anesthetic sleep (30 - 40 minutes) [2-6,9-11]. The second and third groups received the studied substances, namely, Heterosides-21, Heterosides-31 [4-6], the fourth group - SCC [2-6,9-11], the fifth - Piracetam [1,6,12]. Analeptic efficacy was assessed by reducing the duration of anesthesia (DA).

Antihypoxic properties were studied under conditions of normobaric hypoxia with hypercapnia (NBHH) [7,9] in 5 groups of mice $(\mathrm{n}=9-10): 1^{\text {st }}$ control pathology (hypoxia only), the $2^{\text {nd }}$ and the $3^{\text {rd }}$ group were injected with freshly prepared aqueous solutions of Heterosides-21, Heterosides-31, $4^{\text {th }}$ with SCC analeptic, $5^{\text {th }}$ with Piracetam antihypoxant. All substances under study and comparison preparations were injected intraperitoneally 15 minutes before the start of the experiment [7,9]. The criterion of antihypoxic activity was the duration of life (DL) of mice.

The effect on RC was determined by the frequency of respiratory movements per minute (FRM/min) in different phases of anesthesia before and after the administration of the awakening drugs. Indicators DA and FRM/min in mice of the 1st group were considered control, and all other experimental groups were compared with them [2-6,9-11]. The FRM were counted for 60 seconds, starting immediately with the animals adopting a lateral position (LP) after the introduction of the TPA (FRM 1), and the counts were repeated at intervals of ten minutes (respectively, the FRM 2 FRM 9). The introduction of Heterosides-21, Heterosides-31 and SCC in the respective groups was carried out at the peak of anesthesia (thirty-first minute) immediately after counting of FRM 4. The last FRM measurement was performed after complete awakening of the mice (taking position on four legs) [2-6,9-11]. From that moment, their psychomotor state was evaluated (disorientation in space or purposefulness of movement); the level of their adaptation after anesthesia (lethargy or hyperactivity, interest in food and water); physiological reactions (urination, defecation) and other behavioral reactions [4-7]. The reliability of the results obtained was evaluated by the criteria of Newman-Keuls and Mann Whitney (Statistica 10.0 program).

Results and Discussion. Under the experimental conditions, the classic analeptic SCC was the most active, which accelerated the awakening of animals at the optimal dose by $32.5 \%$ (Table 1). The awakening efficacy of Heterosides-21, Heterosides-31 was 28.2 and $27.9 \%$, respectively. Under similar conditions, Piracetam on the contrary prolonged anesthesia by 30.3\% [1,12]. Thus, Heterosides-21, Heterosides-31 at a concentration of 10 times less than SCC practically did not yield to him in awakening efficiency, which indicates the promise of derivatives of sulfur and nitrogen containing heterocycles to search for original analeptics. 
Table 1. Awakening effect of the substances under study, $(n=6)$

\begin{tabular}{|c|c|c|c|c|}
\hline \multirow{2}{*}{ Groups } & \multicolumn{2}{|c|}{ Average duration of anesthesia } & $\begin{array}{c}\text { Awakening } \\
\text { effect }\end{array}$ & $p$ \\
\hline TPA (control group) & $84 \min 41 \sec 5081(4949 ; 5290)$ & $100 \%$ & $0 \%$ & \\
\hline TPA + Heteroside -21 & $60 \mathrm{~min} 47 \sec 3647(3296 ; 3921)^{*}$ & $71.8 \%$ & $-28.2 \%$ & 0.0022 \\
\hline TPA + Heteroside -31 & $61 \min 03 \sec 3663(3592 ; 4213) *$ & $72.1 \%$ & $-27.9 \%$ & 0.0022 \\
\hline $\begin{array}{c}\text { TPA + } \\
\text { Sulfocamphocaine }\end{array}$ & $57 \min 12 \sec 3432(2765 ; 3810)^{*}$ & $67.5 \%$ & $-32.5 \%$ & 0.0022 \\
\hline $\begin{array}{c}\text { TPA + Piracetam } \\
110 \min 21 \sec 6621(5447 ; \\
7924) * / * * / \#\end{array}$ & $130.3 \%$ & $+30.3 \%$ & 0.0021 \\
\hline
\end{tabular}

Notes:

1. $\mathrm{p}$ - the level of statistical significance when comparing samples using dispersion analysis ANOVA,

2. *- the level of statistical significance when comparing samples of the studied groups with a control group using the Mann Whitney test,

3. ** - the level of statistical significance when comparing samples of a group with groups of Heteroside-21 and a group of Heteroside-31 using the Mann Whitney test,

4. \# - the level of statistical significance when comparing samples of a group with a sulfocamphocaine group using the Mann Whitney test.

The behavioral reactions of animals after awakening were symbatic to the type of activity of the studied substances. Groups of mice receiving Heterosides-21, Heterosides-31 had good coordination of movements (moving in a straight line at a fast pace), actively ate and drank water, and had enhanced diuresis. Mice from the SCC group were moving more slowly, along the perimeter of the cage with frequent falls, did not show interest to water and food, urination was rare, and then they completely hibernated (lasting for about 1 hour). The animals of the control group remained stagnant and disoriented for a long time (they frozed or moved slowly, rolled over from one side to the other, carried out circular motions, they completely lost their interest in water and food). After some time, they also fell into a long sleep (1-2 hours), which fully coincides with the classic symptoms of TPA intoxication [2-6,9-11].

Shock, collapse, anesthesia, asphyxia, hypoxia, bacterial intoxication, poisoning with chemical compounds or drugs that suppress the functions of the central nervous system, that is, almost all areas of urgent therapy associated with the development of local or general hypoxia. In this case, the use of analeptics is indicated and logical [1-6,9-11]. Their ability to activate RC and FRM of the brain accelerates oxygenation and blood circulation, which contributes to the reduction of local and general hypoxia. On this basis, it can be assumed that oxygenation (antihypoxic effect) is one of the most important component of the analeptic action. To test this hypothesis, it seemed interesting to compare the AL and AH properties of the studied substances. Studies conducted on the NBHH model showed that the DL of mice under the action of SCC was extended by $35.5 \%$, under the influence of Heterosides-21, Heterosides-31 - by $32.3 \%$ and $33.2 \%$, respectively. In the Piracetam group, this indicator was only $13.2 \%$ higher than the control level (Table 2).

Table 2. Antihypoxic activity of the substances under study

\begin{tabular}{|c|c|c|c|}
\hline Gropus & Duration of life, sec & $\mathrm{p}$ & DL, $\%$ \\
\hline Intact (Control group) $(\mathrm{n}=9)$ & $24 \min 09 \sec 1449.2 \pm 37.9$ & & $100 \%$ \\
\hline Heteroside-21 $(\mathrm{n}=10)$ & $31 \min 58 \sec 1917.6 \pm 119.6^{*}$ & 0.0015 & $132.3 \%$ \\
\hline Heteroside-31 $(\mathrm{n}=10)$ & $32 \min 11 \sec 1930.9 \pm 110.6^{*}$ & 0.0021 & $133.2 \%$ \\
\hline Sulfocamphocaine $(\mathrm{n}=9)$ & $32 \min 44 \sec 1964.0 \pm 65.4^{*}$ & 0.0016 & $135.5 \%$ \\
\hline Piracetam $(\mathrm{n}=9)$ & $27 \min \sec 1641 \pm 57.8^{* *}$ & 0.0315 & $113.2 \%$ \\
\hline
\end{tabular}

Notes:

1. $\mathrm{p}$ - the level of statistical significance when comparing samples using dispersion analysis ANOVA,

2. - the level of statistical significance when comparing samples of the studied groups with a control group using the Newman-Keuls test, 
3. ** - the level of statistical significance when comparing the sample of the studied group with the Heteroside-21 group using the Newman-Keuls test,

4. $\mathrm{n}$ - number of mice in a group.

The symbasis of the of $\mathrm{AH}$ and $\mathrm{AL}$ values (awakening) effects in all the studied substances confirmed our assumption about the key role of antihypoxic properties for the manifestation of analeptic action of the substances, but did not ptovide an idea indication about the mechanism of their implementation. According to our ideas, resistance to hypoxia can be increased in four ways: under aerobic conditions, by activating of RC and FRM, which accelerates natural oxygenation and blood circulation; hypothermic or drug-toxic (anesthesia, anabiosis) suppression of the metabolic activity of tissues; in anaerobic - stimulation of endogenous anaerobic mechanisms of energy supply; a combination of these options.

The rapidity of the NBHH model, the presence of stress, hypercapnic intoxication, and a constant amount of residual air initially excluded the possibility of implementing the first and second mechanisms of AG activity. Under these conditions, only the third option is possible - activation of endogenous anaerobic energy compensation, which, obviously, is provided by the studied Heterosides, SCC and Piracetam.

To study other options for the implementation of the AH effect of the studied substances, the model of TPA of anesthesia developed by us [6] was optimally matched, which makes it possible to adequately assess their effect on RC and FRM of the CNS in various phases of anesthetic sleep. For this, simultaneously with DA, changes in the FRM of animals were recorded. Comparison of the results of FRM in different phases of anesthesia (Table 3) showed that after the introduction of TPA, the FRM 1 - FRM 4 decreases, respectively, from $80 ; 72.5 ; 64.5$ respiratory movements $(\mathrm{RM} / \mathrm{min})$, reaching a minimum of 60.5 $\mathrm{RM} / \mathrm{min}$ (peak of anesthesia) in the control group at 30-40th minute of anesthetic sleep.

Table 3 . The effect of the studied substances on the frequency of respiratory movements

\begin{tabular}{|c|c|c|c|c|c|c|}
\hline Groups & $\begin{array}{c}\text { TPA } \\
\text { (Control } \\
\text { group) }\end{array}$ & $\begin{array}{c}\text { TPA + } \\
\text { Heteroside-21 }\end{array}$ & $\begin{array}{c}\text { TPA + } \\
\text { Heteroside-31 }\end{array}$ & $\begin{array}{c}\text { TPA + } \\
\text { Sulfocam- } \\
\text { phocaine }\end{array}$ & $\begin{array}{c}\text { TPA + } \\
\text { Piracetam }\end{array}$ & $\mathrm{p}$ \\
\hline FRM 1 & \multicolumn{5}{|c|}{$80(72 ; 82) \quad(n=30)$} & 0.7024 \\
\hline FRM 2 & \multicolumn{5}{|c|}{$72.5(65 ; 75) \quad(\mathrm{n}=30)$} & 0.5548 \\
\hline FRM 3 & \multicolumn{5}{|c|}{$64.5(61 ; 69) \quad(n=30)$} & 0.4237 \\
\hline FRM 4 & \multicolumn{5}{|c|}{$60.5(58 ; 64) \quad(n=30)$} & 0.0870 \\
\hline FRM 5 & $\begin{array}{l}58.5(50 ; 60) \\
\quad(\mathrm{n}=6)\end{array}$ & $\begin{array}{l}63(62 ; 65)^{*} \\
\quad(n=6)\end{array}$ & $\begin{array}{c}63(62 ; 65)^{*} \\
(\mathrm{n}=6)\end{array}$ & $\begin{array}{c}85(80 ; 91) \\
* / * * / \# \\
(\mathrm{n}=6)\end{array}$ & $\begin{array}{l}68.5(67 ; 69) \\
* / \# \#(n=6)\end{array}$ & 0.0003 \\
\hline FRM 6 & $\begin{array}{l}59.5(55 ; 64) \\
\quad(n=6)\end{array}$ & $\begin{array}{c}81.5(81 ; 83) \\
(\mathrm{n}=6) *\end{array}$ & $\begin{array}{c}77(72 ; 83) * \\
\quad(\mathrm{n}=6)\end{array}$ & $\begin{array}{c}80 \\
(78 ; 83,5) \\
(\mathrm{n}=4)\end{array}$ & $\begin{array}{c}72.5(72 ; 73) \\
\text { */\#/ \#\# } \\
(\mathrm{n}=6)\end{array}$ & 0.0013 \\
\hline FRM 7 & $\begin{array}{l}65.5(61 ; 70) \\
\quad(n=6)\end{array}$ & $77(76 ; 78) \quad(n=3)$ & $\begin{array}{c}78(76.5 ; 80.5) \\
(\mathrm{n}=4)\end{array}$ & $(\mathrm{n}=0)$ & $\begin{array}{c}79(76 ; 79) \\
(\mathrm{n}=6)\end{array}$ & 1.0000 \\
\hline FRM 8 & $\begin{array}{l}\text { 67.5(66;74) } \\
\quad(\mathrm{n}=6)\end{array}$ & $\begin{array}{c}78(78 ; 78) \\
(\mathrm{n}=1)\end{array}$ & $\begin{array}{c}78(74 ; 82) \\
(\mathrm{n}=2)\end{array}$ & $(\mathrm{n}=0)$ & $\begin{array}{c}81(79 ; 83) * \\
(\mathrm{n}=5)\end{array}$ & 1.0000 \\
\hline FRM 9 & $\begin{array}{c}73.5(58 ; 78) \\
\quad(n=6)\end{array}$ & $(\mathrm{n}=0)$ & $(\mathrm{n}=0)$ & $(\mathrm{n}=0)$ & $\begin{array}{c}82.5(80.5 ; 84)^{*} \\
(\mathrm{n}=4)\end{array}$ & 1.0000 \\
\hline FRM 10 & $(\mathrm{n}=0)$ & $(\mathrm{n}=0)$ & $(\mathrm{n}=0)$ & $(\mathrm{n}=0)$ & $\begin{array}{c}82(81 ; 82) \\
\quad(\mathrm{n}=3)\end{array}$ & 1.0000 \\
\hline FRM 11 & $(\mathrm{n}=0)$ & $(\mathrm{n}=0)$ & $(n=0)$ & $(\mathrm{n}=0)$ & $\begin{array}{c}81(81 ; 81) \\
\quad(\mathrm{n}=2)\end{array}$ & 1.0000 \\
\hline FRM 12 & $(\mathrm{n}=0)$ & $(\mathrm{n}=0)$ & $(\mathrm{n}=0)$ & $(\mathrm{n}=0)^{*}$ & $\begin{array}{c}78(78 ; 78) \\
\quad(n=1)\end{array}$ & 1.0000 \\
\hline
\end{tabular}


Notes:

1. p-the level of statistical significance when comparing samples using dispersion analysis ANOVA,

2. *- the level of statistical significance when comparing the studied groups with a control group using the Mann Whitney test,

3. ** - the level of statistical significance when comparing samples of the studied groups with the Heteroside-31 group using the Mann Whitney test,

4. \# - the level of statistical significance when comparing samples of the studied groups with the Heteroside-21 group using the Mann Whitney test,

5. \#\#- the level of statistical significance when comparing samples of the studied groups with the sulfocamphocaine group using the Mann Whitney test,

6. $\mathrm{n}$ - number of mice in a group,

7. $\mathrm{n}=0-$ all the mice in the group are awake.

After the administration of Heterosides-21, Heterosides-31, SCC and piracetam, during the first 10 minutes there was a significant increase in FRM 5 relative to the control group by $7.7 \%, 7.7 \%$, $45.3 \%$ and $17.1 \%$ and through 20 minutes the FRM 6 reached $37 ;-29.4 ;-34.2 ;-21.8 \%$, respectively, in all groups. Then indicators of FRM 7-10 stabilized in the range of 77-79\% (at the level of FRM 1) until the mice are fully awakened. It should be noted that after the introduction of Piracetam, a systemic increase in the FRM from 68.5 to $81 \mathrm{RM} / \mathrm{min}$ was observed and reached a maximum -82.5 $\mathrm{RM} / \mathrm{min}$ in the FRM 9-10 interval, which exceeded the starting value ( $80 \mathrm{RM} / \mathrm{min}$ ) for 20 minutes, but was not accompanied by the awakening of animals.

The analysis of the FRM dynamics under the influence of the studied substances allows us to note several interesting facts for the interpretation of the mechanisms of their hypertension and AL effects.

First, the maximum FRM value $(85 \mathrm{RM} / \mathrm{min})$ and the speed of its achievement was observed in the SCC group. The speed of RC stimulation (oxygenation) is 37.3\% higher than the Heterosides-21, Heterosides-31 effect and leads animals to a faster awakening; Secondly, the attainment by animals of the Heteroside groups of the starting level of FRM 1 was also accompanied by their awakening. Those and in this case, the FRM of the mice (oxygenation rate) correlated with the rate of awakening (Fig. 1).

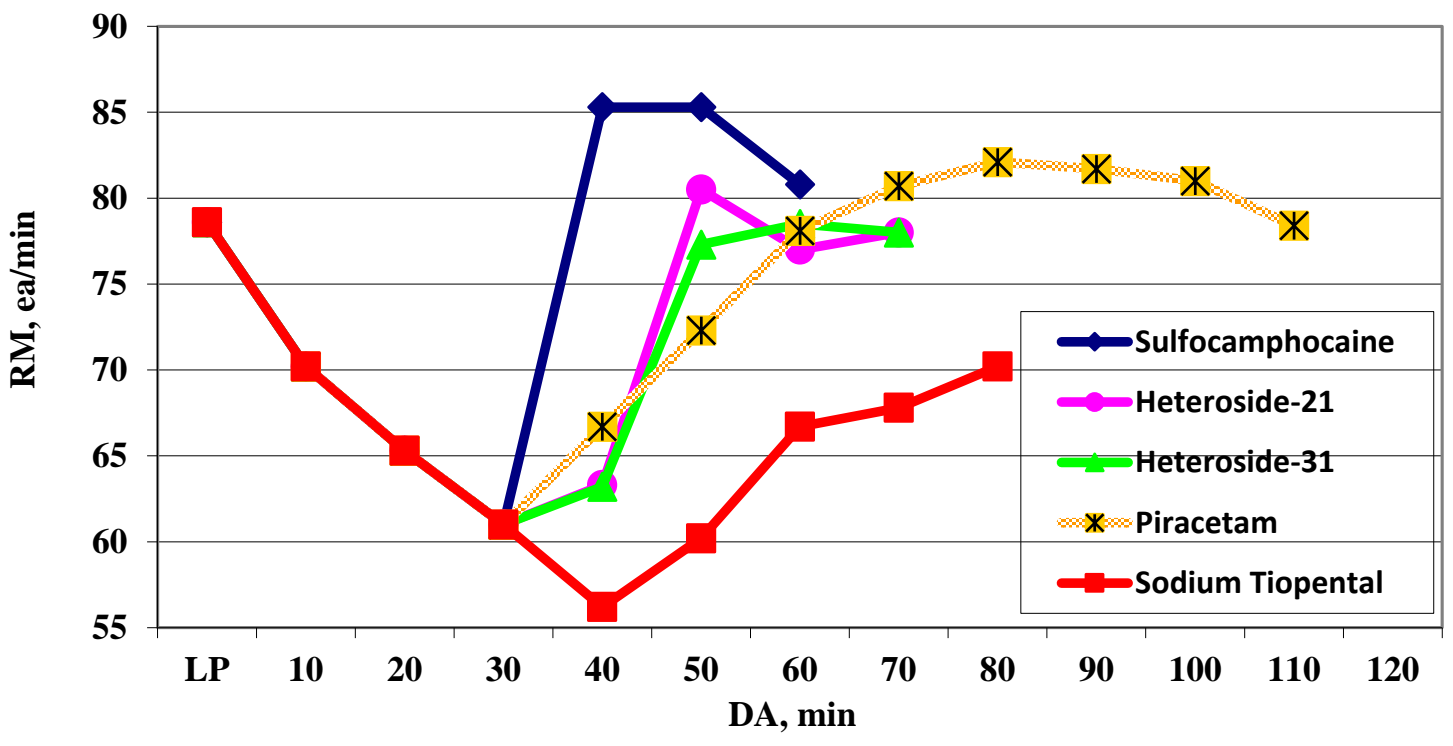

Fig. 1. Dynamics of the respiration rate of the studied substances on the TPA model.

Thirdly, a comparison of the FRM-7, -8, -9 values indicates that in the control group of mice, even after a complete awakening ( $84 \mathrm{~min} 41 \mathrm{sec})$, the FRM was lower $(73.5 \mathrm{RM} / \mathrm{min})$ of the starting level ( $80 \mathrm{RM} / \mathrm{min})$. This means that weaker oxygenation of the organs and tissues causes a later awakening.

Fourthly, Piracetam prolonged anesthesia by $30.3 \%$, exacerbated anesthesia intoxication of TPA for 30 minutes, showed a weak antihypoxic effect $(13.2 \%$ ) (Table 1,2). At the same time, the activity of mice RC in this group was not inferior to the level of its activation by Heterosides-21, Heterosides-31 (FRM 8), SCC (FRM 7) and significantly exceeded control (FRM 9) at the time of awakening of animals of the respective groups. This suggests that the ability of substances to influence the metabolism, 
destruction and elimination of xenobiotics plays a significant role in the realization of AL and AH effects (due to the enhancement or suppression of the enzymatic activity of organs and tissues).

Thus, the mechanism of AL and AH effects of the studied substances depends on the cause of hypoxia. In case of oxygen deficiency, they are realized due to the activation of anaerobic energy supply, which reduces the tissue demand for oxygen. In aerobic conditions - through the activation of the respiratory and vasomotor centers of the central nervous system, accelerating oxygenation and blood circulation. In case of CNS poisoning, the significance of their activation of metabolic destruction and elimination of xenobiotics increases.

The results obtained coincide with the classical ideas about the mechanisms of the effects of TPA, which inhibit the central nervous system in general and the RC in particular [10]; analeptic SCC [4-6,8-10]; clinical symptoms and practice of Piracetam application. This confirms the adequacy of the recommended research model, which allows to qualitatively and quantitatively assess the effect of substances on RC of the CNS, behavioral reactions and ability to metabolic detoxification of xenobiotics [4-10].

\section{Conclusions. Theoretically justified and experimentally confirmed:}

- the model of thiopental anesthesia can serve as a standard for screening selection and evaluating the mechanism of action of universal analeptics and antihypoxants;

- derivatives of sulfur and nitrogen-containing heterocycles are promising for the search for universal analeptics and antihypoxants;

- analeptic effect is determined by the ratio of the complex mechanisms of activation and inhibition of metabolic processes in various brain structures.

\section{REFERENCES}

1. Дроговоз С.М. Фармакология в помощь студенту, провизору и врачу: Учебник-справочник / С.М. Дроговоз, С.Ю. Штрыголь, Е.Г. Щекина. - Х.: Титул, 2013. - 900 с.

2. Кабачна I.В. Детоксицирующее действие Гетерозида-321 при отравлении алкоголем / Кабачная И.В., Дроговоз С.М., Кабачный В.И., Палагина Н.Ю., Кабачный В.В.// Наук. журн. Український вісник психоневрології. - Том 25, - випуск 2 (91). - Харків, 2017. С. 49-52.

3. Кабачна I.В. Цілеспрямований пошук оригінальних субстанцій 3 аналептичною активністю на моделі кетамінового наркозу / Кабачна І.В., Дроговоз С.М., Кабачний В.І., Палагина Н.Ю. // Наук. журн. «Фармакологія та лікарська токсикологія» - №4-5 (55)/2017. С. 27.

4. Кабачна I.B., Дроговоз C.M., Кабачний В.I. Патент UA 121609 на корисну модель, МПКG09B 23/00 (2017.01) / Заявка № и 201706266 від 19.06.17 / Спосіб відбору субстанцій для цілеспрямованого пошуку оригінальних біологічно активних сполук 3 аналептичною активністю на моделі кетамінового наркозу - № и 2017 06212; заявл. 27.06.2017 №256; опубл. 11.12.2017. - Бюл. №23, 2017. - 13 c.

5. Кабачна I.B., Дроговоз С.M., Кабачний В.I. Патент UA 122200 на корисну модель, МПК 2017.01, G01N 33/15 (2006/01), A61D 7/00, A61B 5/11 (2006.01), A61B 5/113 (2006.01) / Заявка № u 2017 07292 від 11.07.2017 / Спосіб відбору субстанцій для цілеспрямованого пошуку оригінальних біологічно активних сполук з аналептичною активністю на моделі алкогольного наркозу - № u 2017 07292; заявл. 11.07.2017 №283; опубл. 26.12.2017. - Бюл. №24, 2017. - 13 с.

6. Кабачна I.B., Дроговоз C.M., Кабачний B.I. Патент UA 121609 на корисну модель, МПК G09B 23/00 (2017.01) / Заявка № u 201804154 від 16.04.18 / Спосіб відбору субстанцій для цілеспрямованого пошуку оригінальних біологічно активних сполук 3 аналептичною активністю на моделі тіопенталового наркозу - № u 2018 04154; заявл. 16.04.18 №9980/3У/18; - 15 с.

7. Миронов, А.В. Руководство по проведению доклинических исследований лекарственных средств / А.В. Миронов, Н. Д. Бунятян, А. Н. Васильева Ги др.1 - Москва: Гриф и К, 2012. - 944 с.

8. Deacon R. M. Housing, husbandry and handling of rodents for behavioral experiments / R. M. Deacon // Nature Protocols. - 2006. - V. 1. - № 2. - P. 936-946.

9. Kabachna I.V. Anti-hypoxic properties of Heterocide - 321 / Kabachna I.V., Plakhotna E.Yu.// Materials of the VIII-National pharmacists congress, Kharkiv, 13-16 September 2016. - P.143.

10. Kabachna I.V. Awakening action of Heterosides on a model of thiopental anestaesia / Kabachna I.V., Storozhenko O.M., Drogovoz S.M., Kabachnyy V.I. // Topical issues of new drugs development: April 1820, 2018.: thes., report - Kharkiv. - P. 261-263.

11. Kabachna I.V., The standartized model of alcohol drugs for certain screening of analeptics / I.V. Kabachna, S.M. Drohovoz, V.I. Kabachnyy, Yu.Yu. Serdiukova // Journal of Clinical Pharmacy - 2017. - V.21, № 4 P. 4-10. ISSN: 1562-725X.

12. Morana H. The effects of piracetam on cognitive performance in a mouse model of Down's syndrome Timothy // H. Morana, George T. Caponeb, Susan Knippa, Muriel T. Davissonc, Roger H. Reevesd, John D./ Gearhart Physiology \& Behavior 77 (2002): 403 - 409.

13. Teresa A. Zimmers Lethal Injection for Execution: Chemical Asphyxiation?/ Jonathan Sheldon; David A. Lubarsky; Francisco López-Muñoz; Linda Waterman; Richard Weisman; Leonidas G. Koniaris// PLoS Med. 2007;4(4) PLoS Med.C 2007 Public Library of Science. Электронный ресурс, Режим доступа: https://www.medscape.com/viewarticle/556167_4 